\title{
QUICK COUNT (Metode Hitung Cepat) DALAM PERSPEKTIF PEMILUKADA
}

\author{
Oleh : \\ Robi Cahyadi Kurniawan \\ Staf Pengajar FISIP Universitas Lampung
}

\begin{abstract}
ABSTRAK
Metode quick count (hitung cepat) mulai merebak ditanah air semenjak diberlakukannya pemilihan umum langsung, baik nasional maupun pemilihan kepala daerah langsung (pilkada). Metode ini dengan cepat menjadi sebuah alternatif baru yang diidolakan para pemangku kepentingan atau pihak-pihak yang terkait dengan perebutan kekuasaan (pemilu) baik dalam skala nasional dan dalam konteks lokal. Penelitian ini dilakukan pada bulan Januari 2012. Metode penelitian yang dipakai adalah kualitatif analisis dengan studi pustaka dan observasi pilkada Kabupaten di Lampung sepanjang tahun 2011.. Hasil penelitian menunjukkan bahwa metode hitung cepat semakin dipercya sebagai sebuah analisis dalam keputusan politik, dalam hal ini memprediksi hasil sebuah pilkada/pemilukada dengan tingkat akurasi yang mendekati perhitungan resmi yang dikeluarkan oleh penyelenggara pemilukada (KPUD Kabupaten).
\end{abstract}

Kata Kunci : Hitung cepat, Pemilukada, Lampung

Key Words : Quick Count, regional election, Lampung

\section{A. PENDAhULUAN}

Metode quick count (hitung cepat) mulai merebak ditanah air semenjak diberlakukannya pemilihan umum langsung, baik nasional maupun pemilihan kepala daerah langsung (pilkada). Metode ini dengan cepat menjadi sebuah alternatif baru yang diidolakan para pemangku kepentingan atau pihakpihak yang terkait dengan perebutan kekuasaan baik dalam skala nasional dan dalam konteks lokal. Quick Count dalam ilmu statistika juga bukan barang baru. Metode ini menjadi buah bibir dikarenakan cara penggunaannya yang tidak terlalu sulit. Pengeluaran anggaran yang tidak terlalu besar serta keakuratan datanya yang dapat menyajikan informasi dengan tingkat ketepatan tinggi.
Publik mendefinisikan Quick Count sebagai cara mengetahui lebih cepat siapa yang menag atau kalah dalam pemilu atau pilkada. Pada hakikatnya Quick Count lahir dari kebutuhan untuk menjaga agar penghitungan suara pemilu tidak dilakukan dengan cara-cara yang curang. Peluang kecurangan memang tetap ada, namun dapat diminimalisir dan diharapkan tidak merubah siapa yang seharusnya menang atau kalah. Metode ini bertujuan, menjaga suara pemilih dan membantu agar proses pemilu berjalan secara jujur dan adil.

Metode ini muncul di negaranegara yang baru membangun demokrasi pada era ahun 1980-an, misalnya di negara Eropa Timur dan Afrika. Kelemahan pada negara demokrasi yang masih baru adalah peluang kecurangan yang terbuka lebar. Kecurangan pada saat 
penghitungan dan tabulasi suara sangat sering terjadi. Runtutannya pada saat di Tempat Pemungutan Suara (TPS), setelah suara dikumpulkan ke Panitia Pemungutan Suara (PPS) di kecamatan, sampai dengan tingkat kabupaten/kota dan provinsi. Pelaksanaan Quick Count di tingkat TPS dan hasilnya dipublikasikan kepada khalayak/publik , maka kecurangan pasca TPS dapat dipotong. Data yang diperoleh dapat menjadi data alternatif terhadap penghitungan yang dilakukan oleh Komisi Pemilihan Umum (KPU). ${ }^{34}$

Quick count atau penghitungan cepat dalam catatan di Asia Tenggara pertama dilakukan pada tahun 1986 di Pemilu Philipina. Sebuah LSM yang bernama NAMFREL melaksanakan PVT (parallel vote tabulation) yaitu pencatatan atau penabulasian secara paralel hasil penghitungan suara pemilu. Indonesia juga menggunakan metode ini era tahun 1990-an. Metode quick count sebenarnya sudah dilaksanakan sejak pemilu 1997 dan pemilu 1999 oleh LP3ES. LP3ES sayangnya, tidak terlalu mempublikasikan secara besar-besaran hasilnya. Seiring berjalannya waktu, teknik yang digunakan dalam quick count semakin berkembang.

Prinsip dasar statistika

mempermudah metode ini, penyelenggara quick count tidak perlu menempatkan orang di setiap TPS. LP3ES menyebutkan quick count atau penghitungan suara cepat adalah proses pencatatan hasil perolehan suara di ribuan TPS yang dipilih secara acak. Quick count

${ }^{34}$ Syaiful Mujani, Direktur LSI, Sumatra Ekspres 2008. adalah prediksi hasil pemilu berdasarkan fakta bukan berdasarkan opini. Karena itu ia tidak sama dengan jajak pendapat terhadap pemilih yang baru saja mencoblos atau yang biasa disebut exit poll.

Untuk kepentingan quick count ribuan relawan diturunkan untuk mengamati pemilu secara langsung demi memperoleh informasi yang diperlukan. Mereka mencatat ke dalam formulir yang telah disediakan mengenai informasi proses pencoblosan dan penghitungan suara di TPS yang diamati, termasuk perolehan suara masing-masing kandidat. Setelah selesai mereka akan menyampaikan temuan-temuannya ke pusat data (data center).

Mengapa kita bisa mempercayai hasil quick count? Pertanyaan ini seringkali diajukan ketika banyak pihak yang meragukan akurasi data. Jawabannya karena quick count tidak mendasarkan diri pada opini siapapun, melainkan berbasis pada fakta lapangan, yaitu perolehan suara di TPS. Organisasi yang melakukan Quick Count mengumpulkan data dari tiap TPS, dan berusaha melakukan penghitungan cepat dari daerah pantauan yang dipilih secara acak. Para pemantau berada di TPS, dan melaporkan secara langsung proses pemungutan dan penghitungan surat suara.

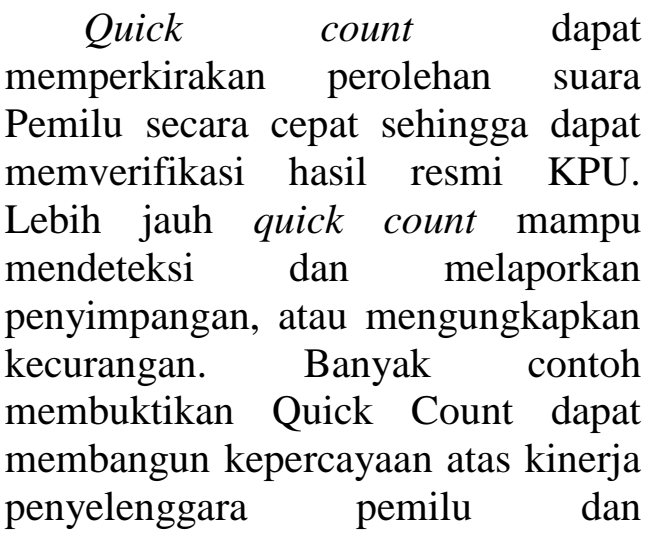


memberikan legitimasi terhadap proses pemilu. Selanjutnya agar kita bisa memahami quick count, kita pun harus mengerti metodologi dan cara penarikan sampel yang dipilih penyelenggara karena kekuatan data quick count sebenarnya bergantung pada bagaimana sampel itu ditarik. Sebab, sampel tersebut yang akan menentukan mana suara pemilih yang akan dipakai sebagai basis estimasi hasil pemilu. Sampel yang ditarik secara benar akan memberikan landasan kuat untuk mewakili karakteristik populasi.

Seberapa akuratkah hasil quick count bila dibandingkan dengan hasil resmi pemilu atau pilkada? Estimasi quick count akan akurat apabila mengacu pada metodologi statistik dan penarikan sampel yang ketat serta diimplementasikan secara konsisten di lapangan. Kekuatan Quick Count juga sangat tergantung pada identifikasi terhadap berbagai faktor yang berdampak pada distribusi suara dalam populasi suara pemilih. Apabila Pemilu berjalan lancar tanpa kecurangan, akurasi quick count dapat disandarkan pada perbandingannya dengan hasil resmi KPU. Tetapi apabila Pemilu berjalan penuh kecurangan, maka hasil quick count dapat dikatakan kredibel meskipun hasilnya berbeda dengan hasil resmi KPU. Oleh karena itu Quick Count biasanya diiringi dengan kegiatan lain yaitu pemantauan yang juga menggunakan metode penarikan sampel secara acak. ${ }^{35}$

\footnotetext{
${ }^{35}$ Iqbal Fadil, Memahami Metode Quick Count, 2007 (www.detiknews.com)
}

\section{B. ATURAN /REGULASI QUICK COUNT}

Menjamurnya lembaga-lembaga survey telah membuata pemerintah perlu melakukan regulasi untuk mengaturnya. Latar belakang yang menyebabkan perlunya hal ini diatur, karena pemerintah menganggap hasilhasil lembaga survey dapat mempengaruhi opini dan wacana publik. Berikut ini regulasi-regulasi terkait penyelenggaraan Survey, Exit Poll dan Quick Count:

1) UU No.16 Tahun 1997 tentang Statistik

- Bagian Ketiga Statistik Khusus Pasal 14: Penyelenggara survei wajib memberitahukan sinopsis hasil survei kepada Balai Pusat Statistik yang memuat: judul, wilayah kegiatan survei, objek populasi, jumlah responden, waktu pelaksanaan,metode statistik, nama, alamat penyelenggara, abstraksi.

2) SK KPU no. 701 tahun 2003 pasal 14 ayat 1

- Penyelenggaraan dan penyampaian hasil jajak pendapat umum, seperti polling dansurvei,olehdan/ atau melalui media massa pada masa kampanye dapat dilakukan sepanjang disertai penjelasan kelebihan dan kekurangan metodologi yang digunakan.

3) Keputusan KPU no. 48 tahun 2004

- Pasal 20 ayat 3: Media elektronik dan setiap pihak yang menggunakan media 
elektronik untuk melaksanakan rubrik jajak pendapat umum mengenai pasangan calon wajib menyebutkan: (a) nama sponsor atau pihak yang membiayai kegiatan tersebut; (b) rumusan pertanyaan yang diajukan; (c) teknik mendapatkan data/.informasi; (d) besarnya sample, karakteristik yang menjadi responden dan cara memilih responden; (e) kapan jajak pendapat dilaksanakan; dan (f) ambang kesalahan.

- Pasal 26: Media elektronik dan cetak atau pihak lain yang melaksanakan jajak pendapat sebagaimana dimaksud dalam pasal 20 dan 21 dilarang memberitahukan atau menyiarkan hasil jajak pendapat dalam bentuk apapun pada masa tenang dan sampai pukul 13:00 waktu setempat pada hari dan tanggal pemungutan suara.

4) Pasal 10 dalam Peraturan KPU no. 40 tahun 2008

- Survei Pemilu hanya dapat dilakukan oleh lembaga yang telah mendapatkan nomor registrasi sebagai lembaga survei dari KPU/ KPU Provinsi/ KPU Kabupaten/ Kota.

- Mengajukan permohonan dengan mengisi formulir pendaftaran

- Mengembalikan formulir pendaftaran.

5) Pasal 245 ayat 3 UU Pemilu, UU No 10 tahun 2008
- Pengumuman hasil perhitungan cepat hanya boleh dilakukan paling cepat pada hari berikutnya dari hari/ tanggal pemungutan suara.

- Selain itu, pelaksana kegiatan penghitungan cepat wajib memberitahukan metodologi yang digunakan dan hasil penghitungan cepat yang dilakukannya bukan merupakan hasil resmi penyelenggaraan pemilu.

6) Ketentuan Pidana

- (Pasal 282) Pengumuman hasil survei pada masa tenang, dipidana degan pidana penjara paling singkat 3 (tiga) bulan dan paling lama 12 (dua belas) bulan dan denda paling sedikit Rp. 3.000.000,- (tiga juga rupiah dan paling banyak Rp. 12.000.000,- (dua belas juta rupiah) - Pasal 282

- (Pasal 307) Pengumuman hasil penghitungan cepat pada hari/ tanggal pemungutan suara, dipidana dengan pidana penjara paling singkat 6 (enam) bulan dan paling lama 18 (delapan belas) bulan dan denda paling sedikit Rp. 6.000.000,- (enam juta rupiah) dan paling banyak Rp. 18.000.000,- (delapan belas juta rupiah)

- (Pasal 308) Jika hasil penghitungan cepat tidak diberitahukan bukan merupakan hasil resmi pemilu, dipidana dengan pidana penjara paling singkat 6 (enam) bulan dan paling lama 18 (delapan belas) bulan dan denda paling sedikit Rp. 6.000.000,- (enam juta rupiah) 
dan paling banyak Rp. 18.000.000,- (delapan belas juta rupiah)

\section{RELASI QUICK COUNT dan PEMILUKADA}

Banyak penyelenggaraan pilkada di tanah air yang menggunakan quick count, selain untuk memprediksi lebih cepat pemenang pilkada juga sebagai alat pengawas bagi kinerja KPU setempat. Penulis menarik contoh pada pelaksanaan Pemilihan Kepala Daerah Provinsi Lampung (Pilgub ) 2008 lalu. Pilgub Lampung 2008 lalu, metode sampel secara acak penentuannya berbasiskan pembagian dan pemilahan pada setiap tingkatan/strata tertentu. Pelaksanaan dilakukan pada 400 TPS dari total jumlah TPS kurang lebih 13.000 buah. Jumlah TPS yang dijadikan sampel ini jika dipersentasekan tidak mencapai 3\% dari total keseluruhan TPS yang ada. Sehingga tidaklah belebihan jika pihak kandidat calon gubernur yang lain mengatakan bahwa hasil perolehan quick count tidak menjadi jaminan dari hasil perhitungan suara yang sebenarnya.

Anggapan demikian ada benarnya, karena selama ini kita selalu dimanjakan oleh hasil perhitungan cepat oleh berbagai lembaga-lembaga survey. Biasanya diumumkan sebelum pengumuman resmi dari KPU sebagai penyelenggara pilkada. Keuntungannya tentu saja hasil pilkada dapat diprediksikan dengan lebih cepat, tetapi dibalik itu seolah ada kesan bahwa pihak yang berwenang menyelenggarakan pilkada, yaitu KPU seolah-olah 'dilangkahi' terlebih dahulu mengenai hasil akhir oleh lembaga lain.

Metode quick count, polling, survey dan berbagai metode lain yang bermuara pada memprediksikan hasil dari sebuah proses politik sudah cukup lama eksis. Metode-metode tersebut berasal dari pendekatan mazhab behavioral yang tumbuh dan berkembang di universitas dan institut di Amerika. Metode ini memiliki keberhasilan yang tinggi, karena mampu mempredikasi hasil akhir dengan tingkat akurasi (ketepatan) yang nyaris sempurna. Keberhasilan metode ini di Amerika diantaranya disebabkan tingkat homogenitas dan sebaran penduduk pada negara-negara bagian yang cukup merata, ditunjang oleh pendidikan politik yang relatif sama. Contohnya bagaimana metode polling dapat memprediksikan Obama lebih unggul dibanding Hillary Clinton dalam pencalonan presiden pada partai Demokrat. Atau bagaimana John McCain dapat mengungguli lawan-lawan politiknya yang lebih tangguh dalam memperebutkan kandidat calon presiden di partai Republik. Bahkan, bagaimana respon publik terhadap calon wakil presiden pilihan McCain, Sarah Palin, Gubernur Alaska yang kurang populer sebelumnya.

Beberapa ahli ilmu sosial di Indonesia pada awalnya meragukan penggunaan teknik-teknik tersebut dalam membaca perilaku politik masyarakat di Indonesia. Alasannya karena heterogenitas yang tinggi, sebaran penduduk yang tidak merata dan tentu saja pendidikan politik yang rendah. Terindikasikan pada tingkat pendidikan, ekonomi serta strata sosial masyarakat Indonesia yang 
memiliki jurang pemisah yang sangat dalam.

Tetapi pada akhirnya hasillah yang berbicara, anak-anak muda yang mengenyam pendidikan dari luar seperti Syaiful Mujani dan Deny JA telah membuktikan pada khalayak bahwa ternyata metode ini bisa dilakukan dimana saja, termasuk di Indonesia. Multi stage random sampling telah mempoluperkan nama mereka. Hal yang perlu diperhatikan dengan menggunakan metode/teknik ini adalah keberanian untuk memprediksi hasil akhir sebuah pilkada dalam kasus Indonesia. Jaminan atau prediksi yang akurat dalam hasil akhir menjadi faktor penting bagi para calon kandidat yang bertarung untuk memakai jasa para lembaga konsultan politik yang biasanya juga berprofesi sebagai lembaga survey.

Akan tetapi agaknya kita jangan terlena dengan hasil polling atau perhitungan cepat yang memiliki tingkat akurasi yang tinggi, karena terkadang juga mengalami kegagalan. Kasus pilkada Jawa Barat yang lalu misalnya, berbagai lembaga survey memprediksikan pasangan Agum Gumelar dan Nu'man Abdul Hakim akan memenangkan pilkada Jawa Barat. Ternyata, yang keluar sebagai pemenang adalah pasangan Ahmad Heryawan dan Dede Yusuf dengan perolehan suara mencapai $40 \%$.

Ibarat pepatah' tidak ada gading yang tak retak', maka kemungkinan akan adanya salah perhitungan atau kegagalan dalam memprediksi hasil pasti selalu ada. Hendaknya perhitungan cepat atau polling hanya sebatas informasi ataupun data yang disampaikan kepada publik untuk diketahui saja, sedangkan hasil akhir menjadi kewenangan dari penyelenggara pemilu/pilkada. ${ }^{36}$ Hubungan quick count dengan pilkada ada pada ranah hasil dari pilkada itu sendiri. Quick Count menjaga agar hasil dari pilkada tetap pada koridor keadilan dan kejujuran. Meminimalisir resiko kecurangan, serta memfasilitasi keinginan publik untuk mendapatkan informasi pembanding sebagai barometer informasi resmi penyelenggara pilkada.

Kejujuran dan keadilan dari sebuah pilkada yang demokratis akan meningkatkan kualitas demokrasi daerah setempat. Peningkatan kualitas demokrasi diharapkan akan berkorelasi dengan peningkatan kualitas pemimpin yang dihasilkan serta kemajuan sebuah daerah. Tesis ini, tetap perlu dilakukan penelitian lebih lanjut, karena fakta dilapangan, menunjukkan bahwa pilkada yang demokratis sekalipun tidak menjamin kemajuan sebuah daerah atau kemakmuran publik setempat.

\section{PILKADA, UPAYA MEMBANGUN DEMOKRASI LOKAL ?}

Memperbincangkan demokrasi dalam konteks lokal ,menjadi kajian menarik saat ini. Hal ini berkenaan dengan terjadinya benturan-benturan yang bersifat substansial dari kajian demokrasi ala barat dengan adat budaya lokal ala Indonesia. Demokrasi secara garis besar berbicara mengenai kebebasan yang berbasiskan dari faham liberal individual. Konteks individualisme dengan menjunjung tinggi hak pribadi individu seorang manusia sangat dihormati.

\footnotetext{
${ }^{36}$ Robi Cahyadi K, Melihat Hasil Hitung Cepat Pilgub, Opini Radar Lampung, 8 September 2008.
} 
Sejarah demokrasi yang dikembangkan oleh Yunani Kuno (-6 sd $-3 \quad$ SM) keputusan politik dijalankan langsung oleh seluruh warga negara berdasarkan suara mayoritas. Tetapi, ketentuan demokrasi berlaku untuk warga negara asli, tidak berlaku untuk budak dan pendatang. Terdapat unsur kasta dan strata kelas dalam hal ini.

Demokrasi masa Romawi berubah menjadi sistem feodal (hubungan tuan tanah dan budak), pemusatan kekuasaan spiritual ditangan Paus, dan perebutan kekuasaan di kalangan bangsawan (kelas menengah). Piagam Magna Charta $(1215 \mathrm{M})$ di Inggris antara Raja John dengan kaum bangsawan menjadi cikal demokrasi modern. Raja John memberikan, mengakui, dan menjamin hak atau privilages kaum bangsawan atas tanah dengan imbalan tertentu (penyerahan dana untuk mendukung perang). Magna Charta menjadi tonggak terkikisnya kekuasaan Raja oleh kaum bangsawan.

Gerakan renaisance (abad 14) dan gerakan reformasi (abad 16) di Eropa , serta gerakan rasionalisme (abad 18) kembali membatasi kekuasaan raja serta agama. Agama dalam hal ini gereja yang berkolaborasi dengan raja agar tidak lagi mengatur kehidupan sosial politik masyarakat kala itu. Hak individu semakin kuat dan tercermin dalam kajian demokrasi dikemudian hari.

Pemikiran-pemikiran demokrasi yang banyak dipakai saat ini, contohnya dalam kajian Locke, Montesqiu, Schumpeter, Di Palma, Dahl, Diamond sampai dengan Held sangat bagus dalam tataran konsep. Konsep ini jika dipakai dalam lokal
Indonesia menjadi bermetamorfosa atau malah berbenturan dengan nilai lokal dan budaya masyarakat kita.

Reformasi telah membuka bebas ruang demokrasi ala barat di tanah Indonesia. Konteks demokrasi dengan cara pemilihan umum langsung serta semakin dihargainya hak individu, hak minoritas serta beragam hal yang dahuu tidak ada bahkan ditabukan dalam era orde baru menjadi magnet pengikat yang kuat. Konteks one man one vote, telah menjadikan suara rakyat begitu berharga, setidaknya dalam hal pemilihan umum, walaupun dalam hal lain, suara rakyat selalu terpinggirkan , misalnya apabila berbenturan dengan kaum elite atau penguasa. Demokrasi ala prosedural atau demokrasi elektoral inilah yang sedang menjadi trend dan eforia perpolitikan nasional dan lokal di Indonesia.

Pertanyaan kemudian adalah, untuk apa kita berdemokrasi ? Mengutip pandangan Plato dan Aristoteles, demokrasi dimaksudkan untuk mencapai good life atau kesejahteraan bagi masyarakat. Timbul pertanyaan lanjutan, sudahkah kita sejahtera dengan demokrasi? Jawabannya mungkin beragam, namun jawaban terbanyak menurut hemat penulis adalah belum.

Kurang lebih 12 tahun reformasi dan menerapkan prinsip-prinsip demokrasi. Apa yang telah kita capai ? Naikkah GNP atau pendapatan perkapita kita ? Semakin berkurangkah pengangguran, semakin berkurangkah kemiskinan atau semakin besarkah peluang anak muda tanah air untuk mendapatkan pekerjaan yang layak ? Secara umum,semakin sejahterakah rakyat kita? 
Otonomi daerah sebagai bagian tidak terpisahkan dari era demokrasi baru tanah air , mencoba menawarkan solusi bagi permasalahan yang menjadi pertanyaan-pertanyaan pada paragraf diatas. Kebebasan dalam mengatur daerah secara mandiri (otonom) yang dibarengi oleh kebebasan masyarakat lokal untuk memilih pemimpinnya sendiri dapat menjadi alternatif jawaban. Mekanisme yang dipakai adalah dengan pelaksanaan pilkada.

Konsep otonomi daerah selama ini ternyata jauh panggang dari api. Otonomi hanya menjadi kenikmatan segelintir elit. Melihat fenomena kekinian ditanah air dan beberapa contoh lokal didaerah, otonomi saat ini tidak jauh berbeda wajahnya dengan sistem kerajaan pada masa raja-raja nusantara dahulu berkuasa. Misalnya; buruknya penempatan pegawai dengan mengesampingkan merit sistem, jual beli jabatan, sampai dengan kolusi dan nepotisme serta korupsi telah menjadikan otonomi surga bagi para elit. Otonomi bagi elit hanya diartikan sebagai kebebasan mereka dalam mengatur daerah sekehendak hati, kemauan serta egoisme pribadi. Janji kampanye dan kontrak politik yang telah ditandatangani tak lebih sebagai pelengkap, pemanis dan alat untuk meraih simpati publik.

Daya tawar publik dalam konteks otonomi daerah saat ini belum dapat dikatakan berimbang. Indikatornya yakni semakin sedikitnya kepentingan publik yang diakomodasi pemerintah, contohnya; coba kita tengok seberapa banyak perda atau keputusan kepala daerah yang menyangkut hajat hidup masyarakat. Atau kita lihat, seberapa besar alokasi dana APBD propinsi, kota, dan kabupaten yang dialokasikan untuk peningkatan kesejahteraan warga.

Oligarki politik atau politik kekerabatan, atau dalam bahasa penulis adalah dinasti politik telah menempatkan elit-elit lokal beserta keluarganya dan anak turunannya menjadi raja kecil didaerah. Jadi, dimana letak demokrasi? Demokrasi tanah air, sepertinya hanya terjadi dalam dua ranah; kontestasi dan partisipasi.

Kontestasi yakni seberapa banyak aktor yang terlibat dan mengajukan diri menjadi pemimpin dalam mekanisme pemilu. Partisipasi yakni seberapa banyak warga negara menggunakan hak pilihnya dalam pemilu. Rakyat atau warga sebagai pemegang kedaulatan tertinggi dalam demokrasi tidak tersentuh, dan hanya dimanfaatkan sebagai alat pendulang suara dalam pemilu.

Otonomi daerah layak sebagai jembatan penghubung demokrasi (dalam konteks prosedural elektional) untuk mendapatkan, menyaring serta memilih pemimpin yang mumpuni. Otonomi dalam hal pemilukada hanya memilih pemimpin lokal dalam hal kuantitas (jumlah) bukan kualitas (akhlak, kinerja dan track record).

Pemimpin yang dihasilkan dengan memilih dengan suara terbanyak mengalahkan mekanisme pemilihan ala Indonesia yang berdasarkan akhlak, kejujuran, amanah serta rasa tanggungjawab. Kesemuanya itu jelas menjadi ciri khas bangsa Indonesia dengan sifat ketimurannya dengan mengedapankan musyawarah, mufakat serta gotong royong.

Hasil memilih pemimpin dengan cara kuantitas sudah jelas terlihat, berapa banyak pejabat publik baik 
dalam jajaran Gubernur, Walikota dan Bupati yang bermasalah, yakni yang berkenaan dengan kasus korupsi. Ini membuktikan bahwa pemilihan dengan cara pemilukada bukanlah menjadi jaminan mendapatkan pemimpin yang mumpuni.

Ada segelintir kepala daerah yang dapat menjadi sebuah contoh akan keberhasilan dalam mengelola otonomi daerah. Misalnya, Sumatra Barat, Gorontalo dalam lingkup Propinsi. Contoh di Kota dan Kabupaten, kita dapat belajar banyak dari Badung, Bandung, Blitar, Bukittinggi, Gowa, Jembrana, Jombang, Limboto, Luwu Timur, Makassar, Solo, Sragen, Tarakan, dan Yogyakarta.

Rahasia dari daerah-daerah itu ternyata terletak dari komitmen kepala daerah masing-masing untuk memajukan daerahnya. Intinya seberapa besar kepala daerah berupaya untuk melakukan inovasi otonomi didaerahnya. Dengan kata lain, faktor peran aktor lokal dalam hal ini Gubernur, Walikota serta Bupati menjadi sangat penting. Merekalah motor penggerak perubahan didaerah.

Peran legislatif dan yudikatif lokal bukanlah tanpa arti, tetapi dengan kualitas mental dan akhlak yang masih dipertanyakan, dengan indikasi maraknya korupsi, maka sekali lagi peran eksekutif menjadi signifikan. Peran signifikan eksekutif ini dapat berjalan jika pemimpin dalam daerah tersebut mengedepankan tanggungjawab dibandingkan harta, jabatan atau capaian ekonomi semata.

Bagaimana cara mendapatkan pemimpin lokal yang mumpuni dan bertanggungjawab? Sumbang saran penulis sebagai berikut ${ }^{37} ;$ Pertama; partai politik harus lebih selektif dalam melakukan rekrutmen politik dan memilih anggotanya untuk ditempatkan dalam jabatan-jabatan politik. Fenomena yang terjadi saat ini, banyak partai yang menepikan kaidah regenerasi politik dan kaderisasi dengan baik. Menjelang pemilu, partai hanya memilih kandidat yang berpotensi mendulang suara terbanyak tanpa memperdulikan kemampuan dan kinerja, contohnya merekrut aktor dan artis untuk jabatan politik, atau putra dan putri pejabat publik dan pimpinan partai.

Kedua; membuka keran seluasluasnya kepada publik untuk berpartisipasi dalam memperebutkan jabatan politik. Aktor lokal yang mampu dan berkualitas hendaknya ditampilkan oleh segenap elemen masyarakat . Jika partai tidak memberikan kesempatan, maka calon independenlah alternatif lain, walau kesaktiannya dalam pemilu belum teruji mumpuni, kecuali di tanah rencong Aceh. Ketiga; selektifitas publik atau warga negara yang mempunyai hak untuk memilih dalam pemilu. Rasionalitas lebih diutamakan dibandingkan emosional, kolegial, kekerabatan atau bahkan politik uang. Keempat ; netralitas media. Media cetak maupuan elektronik hendaknya tidak terlalu dalam keberpihakannya terhadap satu kandidat tertentu. Unsur pendidikan politik yang santun serta etika media menjadi fungsi kontrol media untuk memberi informasi yang akurat, berimbang dan membuka wawasan publik.

\footnotetext{
${ }^{37}$ Robi Cahyadi K, Demokrasi, Otonomi dan Aktor Lokal, Opini Lampung Post, 13 April 2010
} 


\section{E. KESIMPULAN}

Peneliti mencoba memberikan pendapat bahwa Quick Count menjadi penting dalam beberapa hal: (a) Mencegah terjadinya kecurangan dalam pilkada, pengumuman sebuah lembaga survey terhadap sebuah pemilu akan mencegah aparat yang akan berbuat curang untuk berfikir ulang. Melaui cara mengidentifikasi terjadinya kecurangan dengan mencatat inkonsistensi antara hasil yang didapat (hasil quick count) dengan hasil resmi KPU; (b) Memprediksi hasil penghitungan suara; (c) Meningkatkan kepercayaan terhadap proses pemilu dan hasil akhir melalui laporkan kualitas proses pemilu dengan data kualitatif yang diperoleh; (d) Mendorong partisipasi masyarakat untuk peduli dan menjadi relawan pemantauan.

Relasi quick count dengan pilkada hanya sebatas pada hasil akhir penghitungan suara, tingkat kejujuran penyelenggara serta partisipasi publik untuk tutut aktif memantau penghitungan suara. Perspektif lebih jauh, yaitu jika mengkaitkankaitkan quick count, hasil pilkada, aktor yang terpilih dengan demokrasi lokal perlu diteliti lebih lanjut. Peran quick count hanya sepanjang hasil pilkada. Pilkada yang dihasilkan belum tentu menjamin diperolehnya pemimpin yang berkualitas. Kelemahan pemilihan langsung kita, hanya memilih pemimpin yang dihasilkan dari angka dan hitung-hitungan saja. Dalam realitanya, pilkada yang jujur dan adil dengan peran quick count didalamnya, tidak serta merta menjamin kesejahteraan publik . Artinya seorang pemimpin yang dihasilkan dalam pilkada belum tentu berpihak pada publik.

Akhir kata, metode-metode statistika yang digunakan, baik quick count, exit polling atau survey hendaknya dapat berkorelasi dengan aspirasi publik dalam meningkatkan kesejahteraan dan daya tawar publik terhadap kekuasaan. Peranan metodemetode statistik diatas dapat merangkum keinginan masyarakat, untuk setidaknya dipublikasikan dan menjadi bahan evaluasi bersama bagi pemerintah, stake holder, publik, pasar serta lembaga-lembaga yang berkepentingan didalamnya.

\section{F. DAFTAR PUSTAKA}

Almond, Gabriel and Powell, John ; 1965, Comparative Politics: A Developmental Approach, Little Brown and Company, Boston.

Dahl, Robert A. 1971. Polyarchy: Participation and Opposition, Yale University Press, Chelsea

Estok, Mellisa, and Neil Nevitte, Glenn Cowan, 2002. The Quick Count and Election Observation: Handbook for Civic Organizations and Political Parties PenerbitNational Democratic Institute for International Affairs,

Held, David ; 2007, Models of Democracy, Akbar Tandjung Institute, Jakarta

Hirst, Paul; 1990. Representative Democracy and Its Limits, Polity Press, Cambridge.

J.A, Denny; 2006, Election Watch : Merentas Jalan Demokrasi, Penerbit Pustaka Sinar Harapan

Kaloh, Johan; 2007. Mencari Bentuk Otonomi Daerah, Suatu Solusi dalam Menjawab Kebutuhan 
Lokal dan Tantangan Global , Penerbit Rineka Cipta

Lijphart, Arend: 1999, Patterns of Democracy, Yale University Press and New Haven and London.

Luwarso, Lukas ; 2005, Pers dan Pilkada, Penerbit : Kerjasama Dewan Pers dengan Friedrich Ebert Stiftung

Surbakti, A. Ramlan; 1983, Pengantar Ilmu Politik I, Bagian Penerbitan dan Penggandaan FISIP UNAIR, Surabaya

Syaefudin Asep, 1997, Statistika Dasar, Penerbit Grasindo

\section{G. UNDANG-UNDANG DAN} PERATURAN

UU No 10 tahun 2008 tentang Pemilihan Umum Anggota Dewan Perwakilan Rakyat, Dewan Perwakilan Daerah dan Dewan Perwakilan Rakyat Daerah

UU No.16 Tahun 1997 tentang Statistik

Peraturan KPU No. 40 tahun 2008 tentang Partisipasi Masyarakat dalam Pemilihan Umum Anggota Dewan Perwakilan Rakyat, Dewan Perwakilan Daerah, Dewan Perwakilan Rakyat Daerah Provinsi, Kabupaten/Kota serta Pemilihan Umum Presiden dan Wakil Presiden.

Keputusan KPU No. 48 tahun 2004 tentang Kampanye

Keputusan KPU No. 701 tahun 2003 tentang Kampanye Pemilihan Umum Anggota Dewan Perwakilan Rakyat, Dewan Perwakilan Daerah dan Dewan Perwakilan Rakyat Daerah.

\section{H. WEB DAN MEDIA}

www.detiknews.com, 2010

Lampung Post, 2010

Sumatra Ekspres, 2008

Radar Lampung, 2008 